\title{
Preliminary Studies of Organochlorine Pesticides (OCPs) in Sediment, Water and Fish Samples from Ethiope River, Abraka Axis, Southern Nigeria
}

\author{
Oghenekohwiroro Edjere ${ }^{\mathrm{a}^{*}}$, Justina E. Ukpebor ${ }^{\mathrm{b}^{* *}}$, Samuel Emebu \\ and Felix E. Okieimen ${ }^{\mathrm{b}, \mathrm{d}}$
}

aDepartment of Environmental Management and Toxicology, Federal University of

Petroleum Resources, Effurun, Delta State, Nigeria

bDepartment of Chemistry, University of Benin, Benin City, Nigeria.

${ }^{\circ}$ Chemical Engineering Department, University of Benin, Benin City, Nigeria

${ }^{d}$ GeoEnvironmental and Climate Change Adaptation Research Centre

\author{
*Corresponding Author: Email: edjere.oghenekohwiroro@fupre.edu.ng Tel: +2347088102415 \\ ${ }^{* *}$ Current Affiliation, Lancaster Environment Centre, Lancaster University, Lancaster LA14YQ, UK.
}

Keywords: Organochlorine Pesticide, Water, Sediment, Fish.

\begin{abstract}
Selected persistent organochlorine pollutants, including DDT and its metabolites, hexachlorobenzene, dieldrin, Aldrin, heptachlor, $\mathrm{HCH}$ as well as some of their isomers were determined in water, sediment and fish samples from the Ethiope River in Southern Nigeria. Twenty organochlorine pesticides were detected in both seasons from October 2012 - September 2013. Results revealed $\sum \mathrm{HCH}$ to be $0.620 \mu \mathrm{g} / \mathrm{L}$ (water), $33 \mathrm{ng} / \mathrm{g}$ (sediment) and $29.00 \mathrm{ng} / \mathrm{g}$ (fish) for the rainy season while concentrations of $0.170 \mu \mathrm{g} / \mathrm{L}$ (water), $14 \mathrm{ng} / \mathrm{g}$ (sediment) and $28.00 \mathrm{ng} / \mathrm{g}$ (fish) were obtained for the dry season. $0.05-0.15 \mathrm{ng} / \mathrm{g}$ for aldrin, $0.12-5.8 \mathrm{ng} / \mathrm{g}$ for dieldrin, $0.22-$ $0.64 \mathrm{ng} / \mathrm{g}$ for endrin, $0.24-6.37 \mathrm{ng} / \mathrm{g}$ for endosulfan and $0.21-8.81 \mathrm{ng} / \mathrm{g}$ for $\Sigma D D T$ (p, ${ }^{`}$-DDD, $\mathrm{p}$, p '-DDE, p, p' -DDT). Among the OCPs, $\sum \mathrm{HCH}$, endosulfan and PDDT were the most dominant compounds in the river sediments. $\gamma-\mathrm{HCH}$ was the most frequent detected compound in all the samples from this river. Among the cyclodiene compounds, aldrin was in abundance in most of the sediments, water and fish samples. $\gamma-\mathrm{HCH}, \gamma-\mathrm{HCH}$ and $\mathrm{HCB}$ contributed this highest value for the water, sediment and fish sample respectively in the rainy season while aldrin, endrin and HCB were the highest contributors to the $\Sigma$ OCPs to the mean of water, sediment and fish respectively. Hazard quotient and bioaccumulation analysis carried out on the fish sample revealed that the fishes were heavily contaminated with values $>1$ for both seasons which possess a possibility for ecological concern.
\end{abstract}

\subsection{Introduction}

Organochlorine pesticides (OCPs) find wide domestic, industrial and agricultural applications because of the effectiveness in their control of a variety of pests. OCPs such as hexachlorocyclohexanes (HCHs) and dichlorodiphenyltrichloroethane (DDTs) have been of great global concern because of their environmental persistence and toxicity to non- target organisms [13]. Although most of the organochlorine pesticides have been banned, they are continuously being detected in water, air and soil [4-8]. As a result of their ability to resist biodegradation, low polarity, low aqueous solubility and high lipophilicity they can be concentrated through food chains and produce a significant magnification of the original concentration at the end of the food chain [9]. The increasing production and application of pesticides for agricultural and non-agricultural purposes has caused the pollution of air, soil and surface water. This will have a negative impact on the environment as well as human health due to direct exposure or through residues in food and drinking water. 
Pesticide residues reach the aquatic environment through direct run-off, leaching, careless disposal of empty containers, equipment washings [10,11]. OCPs have a capacity of strong affinity for suspended particulate matter. Under favorable conditions, these contaminants could be released from suspended particulate matter into water and then pass onto people through consumption of drinking water, fish and agriculture food [1]. Nigeria has a strong and growing agricultural sector, which requires increased and wide use of pesticides. In Nigeria, OCPs find applications for agricultural purposes and especially for the control of mosquitoes [12,13] with over 100 different brands of pesticides being imported into the country annually [14]. However, there is a dearth of information on the concentration of these chemicals within these regions that would serve as a baseline for future research. This study was therefore designed with the aim to survey the levels and distributions of OCPs in water, sediment and fish samples from the Ethiope River. This research set out to provide extensive screening of some selected OCPs in the water, sediment and biota from a river in the southern part of Nigeria.

\subsection{Materials and Methods}

\subsection{Chemicals}

Analytical grade pesticide standards ( $>97 \%$ purity) was obtained from EGT, Fluka, LGC Promochem, Restek, Ehrenstorfer and Separtis.

\subsection{Study Area}

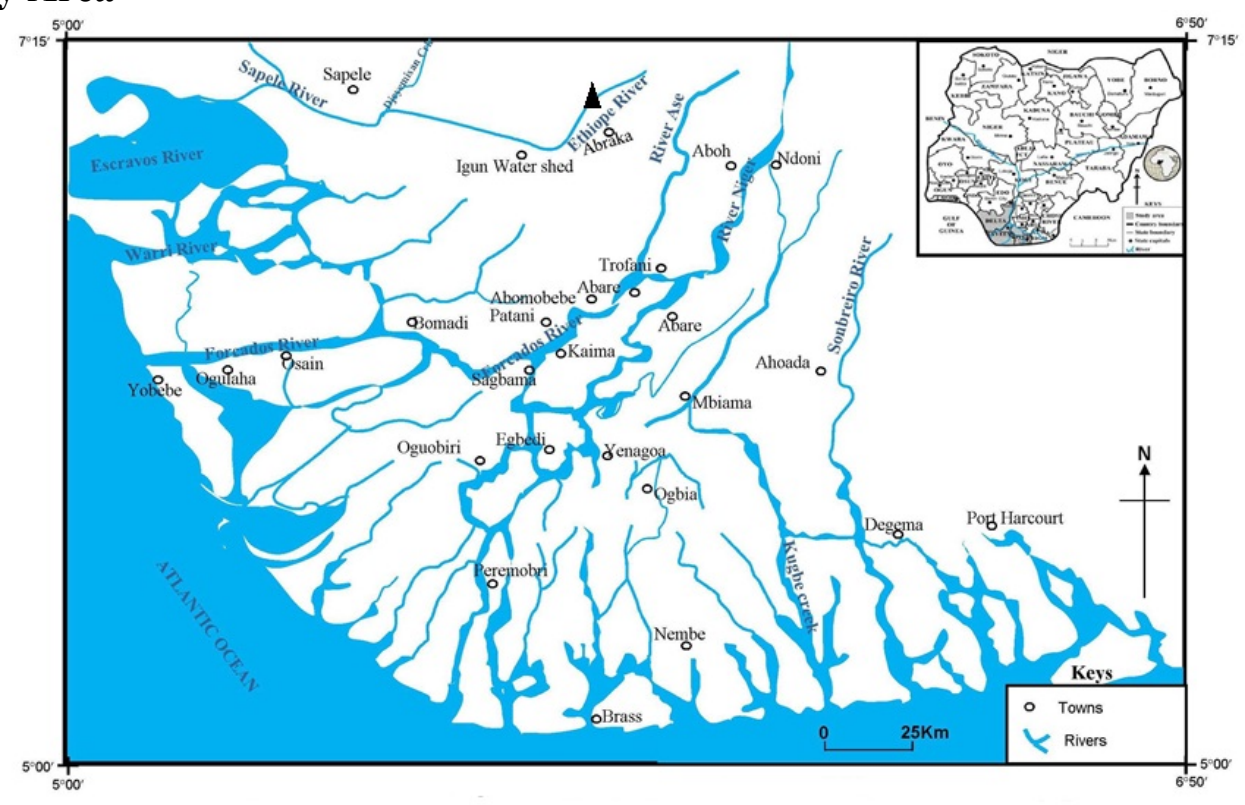

Figure 1: Map showing study location at River Ethiope Abraka Axis in the Niger Delta region of Nigeria

The study area at River Ethiope Abraka Axis is located in the Niger Delta of Nigeria which is the second largest delta in the world and the largest mangrove swamps in Africa [15]. It spans over 20,000 square kilometers. The Niger Delta region is located at latitudes $5^{\circ} 31^{\prime} \mathrm{N}$ and $5^{\circ} 33^{\prime} \mathrm{N}$ and longitudes $5^{\circ} 30^{\prime} \mathrm{E}$ and $5^{\circ} 32^{\prime} \mathrm{E}$. The Niger Delta covers an area of $70,000 \mathrm{~km}^{2}$ of marshland, creeks, tributaries and lagoons that drains the Niger River into the Atlantic at the Bight of Biafra. The coastal region cuts across ten (10) states in southern Nigeria. This region has an estimated population of over 30 million people, with fishing and farming as the main source of livelihood and sustenance. Economic activities include oil and gas exploration and exploitation, fishing industries, shipping, agriculture and tourism.

\subsection{Sampling and Parameter Measurements}

Sampling was carried out during October 2012 - September 2013. All samples were collected from Ethiope River during the wet season (March to September) and dry season (October to February). A 
total of 18 samples made up of 6 samples each for water, sediment and fish (T. zilli) were collected and analyzed. Although twenty-six (26) different organochlorine pesticides were investigated in this work, only twenty-two (22) organochlorine pesticides were detected in the samples collected. The grab sampling technique was employed for the collection of all the water samples at about $1 \mathrm{~m}$ below surface using a $1.0 \mathrm{~L}$ amber bottle. The samples was collected, the $\mathrm{pH}$ of the water samples were taken immediately using a portable $\mathrm{pH}$ meter, and then refrigerated at $<4^{\circ} \mathrm{C}$ until further analysis.

\subsection{Sediment samples}

Sediment samples were collected with the aid of a grab sampler, air dried and then 50 to $100 \mathrm{~g}$ of sample were measured. $20 \pm 0.5 \mathrm{~g}$ sodium sulphate was then added. The samples were spiked with PCB Nr. 209 and Tetramethylxylene (TMX) (surrogates) (Ehrenstofer Germany). $200 \mathrm{~mL}$ of cyclohexane: acetone (50:50) used for extraction was then added. The resulting solution was sonicated for about 20 minutes and then transferred to a mechanical shaker for about two hours. Aliquots of the extract were then taken for analysis. Extraction efficiency, as indicated by recovery of the surrogate standards (TMX), was consistently $78 \% \pm 8 \%$.

\subsection{Water Samples}

$1 \mathrm{~L}$ water sample was measured into a calibrated Erlenmeyer flask and $1 \mathrm{~mL}$ internal standard (ISTD) spike solution $(2.5 \mu \mathrm{L} \mathrm{1-Br-dodecane} \mathrm{in} 250 \mathrm{~mL}$ cyclohexane) $50 \mu \mathrm{L}$ PCB Nr. $209+50 \mu \mathrm{L}$ TMX (surrogates) $+5 \mathrm{~mL}$ cyclohexane were then added. Liquid/Liquid Extraction (LLE) was carried out for one hour. The solvent extract was then transferred into a $10 \mathrm{~mL}$ vial and gently blown down using nitrogen gas ( $>98 \%$ purity) to $1 \mathrm{~mL}$.

\subsubsection{Sample Clean Up}

Sample clean-up was carried out on the water sample extract using silica based Solid Phase Extraction (SPE) cartridges. A combined double effect Isolute 1g FL 712-0100-C (Biotage, Sweden) and Resprep $500 \mathrm{mg}$ carboprep 90 (Restek, USA) SPE cartridge was used as previously reported by Maier [16]. The cartridges were pre-conditioned using $\sim 10 \mathrm{~mL}$ of the cyclohexane: acetone (99: 1) under very low vacuum condition ( $\sim 0.51 \mathrm{psi}) .1 \mathrm{~mL}$ extract was introduced directly unto the cartridge and eluted with $\sim 50 \mathrm{~mL}$ of (cyclohexane: acetone). The collected eluent was then concentrated with the aid of a rotary evaporator (Buchi Syncore, UK) to $\sim 3 \mathrm{~mL}$ and then blown down with nitrogen gas. $2.5 \mu \mathrm{L}$ internal standard solution (1-Br-Dodecane) was then added and finally made up to $1 \mathrm{~mL}$ ready for $\mathrm{GC}$ injection.

\subsection{Analytical Determination}

Separation of the different analytes was done using a GC ECD (Agilent UK) coupled with two separate capillary columns (A and B) Column 1: RTX-CL Pesticides 1. Column 2: RTX-CL Pesticides 2, both columns were subjected to the same temperature programming and constant pressure flow. $2 \mu \mathrm{L}$ extract was injected in split-splitless mode into the GC inlet with temperature of $200^{\circ} \mathrm{C}$ and a constant flow of $2.7 \mathrm{~mL} / \mathrm{min}$. Separation was done using a gradient oven temperature programme $\left(120^{\circ} \mathrm{C}\right.$, held for $1 \mathrm{~min}$, then ramped to $320^{\circ} \mathrm{C}$ at a rate of $9^{\circ} \mathrm{C} / \mathrm{min}$., and held for $3 \mathrm{~min}$ ). A seven point calibration curve using internal standard was prepared to determine the concentrations of organochlorines in the different samples. Laboratory and method blanks were also carried out simultaneously to ensure good QA/QC and also to eliminate any background contamination.

\subsection{Data Analysis and Statistics}

Data Interpretation was done using STAR Varian/Agilent Workstation software solution and was analyzed separately for each sample. Statistical analysis was carried out using Excel and SPSS.

A two-way ANOVA between groups was conducted to explore the variation in OCPs over the location and matrices. The description of the data was done in the form of mean $( \pm)$ SD for quantitative data and frequency and proportion for qualitative data representation. On the environmental significance of the apparent elevated levels of OCPs in the Niger Delta region, evaluation was made in terms of bioaccumulation index and hazard quotient (Kannan et al., 
1995; Qiu et al., 2005). Hazard quotient would be calculated for the parameters using the formula: $\mathrm{HQ}=\frac{\mathrm{C}_{\mathrm{metal}}}{\mathrm{QG}}$, were $\mathrm{C}_{\text {metal }}$ is the concentration of metal in the sample and $\mathrm{QG}$ is the quality guideline for the parameter.

\subsection{Results and Discussions}

This study investigated OCPs in river Ethiope during the two predominant seasons (rainy and dry season). OCPs including HCB, p, p'-DDD, p, p' - DDE, p, p' - DDT, $\alpha-\mathrm{HCH}, \beta-\mathrm{HCH}, \gamma-\mathrm{HCH}$ (lindane), $\delta-\mathrm{HCH}$, endrin, heptachlor, aldrin, dieldrin, in water, sediment and fish samples. The concentrations of the OCPs for the rainy season are presented in Table 1. From the results obtained aldrin was observed to have the highest concentration with values of $0.411 \pm 0.050 \mu \mathrm{g} / \mathrm{L}$ in the water samples while endrinaldehyde reported the lowest concentration of $0.010 \pm 0.00 \mu \mathrm{g} / \mathrm{L}$. $\alpha-\mathrm{HCH}, \beta-$ $\mathrm{HCH}, \varepsilon-\mathrm{HCH}$, dieldrin and $\mathrm{o}, \mathrm{p}-\mathrm{DDE}$ were not detected in the water samples. For the sediment samples the highest concentration of $30 \mathrm{ng} / \mathrm{g}$ was reported for $\gamma-\mathrm{HCH}$ while the lowest concentrations of $1.0 \mathrm{ng} / \mathrm{g}$ was recorded for $\alpha-\mathrm{HCH}$, endrin, Aldrin, $\mathrm{p}, \mathrm{p}$ ' - DDD, endrinaldehyde and endrinketone. $\mathrm{B}-\mathrm{HCH}, \varepsilon-\mathrm{HCH}$, heptachlor, $\gamma$ - heptachlor, $\mathrm{HCB}$ and $\mathrm{o}, \mathrm{p}-\mathrm{DDE}$ were not detected. The fish samples obtained during the rainy season revealed the highest concentration of $30 \mathrm{ng} / \mathrm{g}$ for aldrin and the lowest concentration of $0.05 \mathrm{ng} / \mathrm{g}$ for HCB. Heptachlor, $\gamma$ - heptachlor, $\mathrm{o}$, p- DDD, p, p- DDD and endrinketone were however not detected.

$\sum \mathrm{HCH}$ was found to be $0.620 \mu \mathrm{g} / \mathrm{L}, 33.00 \mathrm{ng} / \mathrm{g}$ and $29.00 \mathrm{ng} / \mathrm{g}$ for the water, sediment and fish samples respectively while the $\sum$ DDT was found to be $0.290 \mu \mathrm{g} / \mathrm{L}$ for the water samples, $11.00 \mathrm{ng} / \mathrm{g}$ for the sediment samples and $9.00 \mathrm{ng} / \mathrm{g}$ for the fish samples. $\sum$ OCP for the different samples collected during the rainy season was found to be $1.402 \pm 0.120 \mu \mathrm{g} / \mathrm{L}$ for the water samples, $52.00 \pm 10.00 \mathrm{ng} / \mathrm{g}$ for the sediment samples and $78.00 \pm 30.00 \mathrm{ng} / \mathrm{g}$ for the fish samples.

Table 1: Distribution of organochlorine pesticides in water, sediment and fish samples collected in the rainy season for River Ethiope at Abraka

\begin{tabular}{|c|c|c|c|}
\hline \multirow[t]{2}{*}{ Pesticide } & \multicolumn{3}{|c|}{ Concentration } \\
\hline & Water $(\mu \mathrm{g} / \mathrm{L})$ & Sediment (ng/g) & Fish (ng/g) \\
\hline$\alpha-\mathrm{HCH}$ & ND & $1.00 \pm 0.00$ & $5.00 \pm 0.00$ \\
\hline$\beta-\mathrm{HCH}$ & ND & ND & $1.00 \pm 0.00$ \\
\hline$\delta-\mathrm{HCH}$ & ND & $2.00 \pm 0.00$ & $2.00 \pm 0.00$ \\
\hline$\varepsilon-\mathrm{HCH}$ & ND & ND & $4.00 \pm 0.00$ \\
\hline$\gamma-\mathrm{HCH}$ & $0.620 \pm 0.060$ & $30.00 \pm 10.00$ & $17.00 \pm 0.00$ \\
\hline$\sum \mathrm{HCH}$ & 0.620 & 33.00 & 29.00 \\
\hline Endrin & $0.020 \pm 0.00$ & $1.00 \pm 0.00$ & $3.00 \pm 0.00$ \\
\hline Heptachlor & $0.020 \pm 0.00$ & ND & ND \\
\hline$\gamma$-heptachlor & $0.020 \pm 0.010$ & ND & ND \\
\hline $\mathrm{HCB}$ & ND & ND & $0.050 \pm 0.010$ \\
\hline Aldrin & $0.411 \pm 0.050$ & $1.00 \pm 0.00$ & $36.00 \pm 10.00$ \\
\hline Dieldrin & ND & $4.00 \pm 0.00$ & ND \\
\hline $\mathrm{o}, \mathrm{p}-\mathrm{DDD}$ & $0.050 \pm 0.00$ & ND & ND \\
\hline $\mathrm{p}, \mathrm{p}^{\prime}-\mathrm{DDD}$ & $0.020 \pm 0.00$ & $1.00 \pm 0.00$ & ND \\
\hline $\mathrm{p}, \mathrm{p}^{\prime}-\mathrm{DDE}$ & $0.030 \pm 0.00$ & $5.00 \pm 0.00$ & $2.00 \pm 0.00$ \\
\hline $\mathrm{o}, \mathrm{p}-\mathrm{DDE}$ & ND & ND & $2.00 \pm 0.00$ \\
\hline$o, p-D D T$ & $0.170 \pm 0.00$ & $2.00 \pm 0.00$ & $4.00 \pm 0.00$ \\
\hline $\mathrm{p}, \mathrm{p}^{\prime}-\mathrm{DDT}$ & $0.020 \pm 0.00$ & $3.00 \pm 0.00$ & $1.00 \pm 0.00$ \\
\hline$\sum$ DDT & 0.290 & 11.00 & 9.00 \\
\hline Endrinaldehyde & $0.010 \pm 0.00$ & $1.00 \pm 0.00$ & ND \\
\hline Endrinketone & $0.011 \pm 0.00$ & $1.00 \pm 0.00$ & $1.00 \pm 0.00$ \\
\hline$\sum \mathrm{OCP}$ & $1.402 \pm 0.120$ & $52.00 \pm 10.00$ & $78.00 \pm 30.00$ \\
\hline
\end{tabular}


The dry season samples showed the water samples had a mean value of $1.152 \pm 0.270 \mu \mathrm{g} / \mathrm{L}$ (Table 2) with concentrations for the more popular OCPs found to be in the order aldrin $>\gamma-\mathrm{HCH}>\mathrm{o}$, pDDT $>$ heptachlor $>$ p,p -DDE $>$ dieldrin $>$ endrin. For the sediment samples, endrin was observed to record the highest concentration $(18.00 \mathrm{ng} / \mathrm{g})$; the order was found to be endrin $>0, p-D D T>$ aldrin $>\mathrm{p}, \mathrm{p}^{\prime}$-DDE with a total value ( $\sum$ OCPs) for sediment as $73.00 \pm 30.00 \mathrm{ng} / \mathrm{g}$ and $128.00 \pm 30.00 \mathrm{ng} / \mathrm{g}$ for fish samples The fish samples revealed HCB $(32.00 \mathrm{ng} / \mathrm{g})$, aldrin $(25.00 \mathrm{ng} / \mathrm{g})$, o, p-DDE $(21.00 \mathrm{ng} / \mathrm{g})$ and $\mathrm{p}, \mathrm{p}^{\prime}-\mathrm{DDE}(16.00 \mathrm{ng} / \mathrm{g})$ to be the most occurring OCPs in the fish sample with detection in $100 \%$ of samples collected.

Table 2: Distribution of organochlorine pesticides in water, sediment and fish samples collected in the dry season for River Ethiope at Abraka

\begin{tabular}{|c|c|c|c|}
\hline \multirow[t]{2}{*}{ Pesticide } & \multicolumn{3}{|c|}{ Concentration } \\
\hline & Water $(\mu \mathrm{g} / \mathrm{L})$ & Sediment (ng/g) & Fish (ng/g) \\
\hline$\alpha-\mathrm{HCH}$ & ND & $3.00 \pm 0.00$ & $5.00 \pm 0.00$ \\
\hline$\beta-\mathrm{HCH}$ & ND & ND & $2.00 \pm 0.00$ \\
\hline$\delta-\mathrm{HCH}$ & $0.010 \pm 0.00$ & $1.00 \pm 0.00$ & $11.00 \pm 0.00$ \\
\hline$\varepsilon-\mathrm{HCH}$ & ND & ND & $5.00 \pm 0.00$ \\
\hline$\gamma-\mathrm{HCH}$ & $0.160 \pm 0.010$ & $10.00 \pm 0.00$ & $5.00 \pm 0.00$ \\
\hline$\sum \mathrm{HCH}$ & 0.170 & 14.00 & 28.00 \\
\hline Endrin & $0.020 \pm 0.010$ & $18.00 \pm 0.00$ & $2.00 \pm 0.00$ \\
\hline Heptachlor & $0.090 \pm 0.040$ & ND & ND \\
\hline$\gamma$-heptachlor & $0.027 \pm 0.010$ & ND & ND \\
\hline $\mathrm{HCB}$ & ND & $3.00 \pm 0.00$ & $32.00 \pm 10.00$ \\
\hline Aldrin & $0.512 \pm 0.090$ & $14.00 \pm 10.00$ & $25.00 \pm 10.00$ \\
\hline Dieldrin & $0.037 \pm 0.030$ & ND & ND \\
\hline $\mathrm{o}, \mathrm{p}-\mathrm{DDD}$ & $0.030 \pm 0.020$ & $1.00 \pm 0.00$ & ND \\
\hline$p, p^{\prime}-D D D$ & $0.020 \pm 0.010$ & $1.00 \pm 0.00$ & ND \\
\hline $\mathrm{p}, \mathrm{p}^{\prime}-\mathrm{DDE}$ & $0.053 \pm 0.020$ & $1.00 \pm 0.00$ & $16.00 \pm 0.00$ \\
\hline $\mathrm{o}, \mathrm{p}-\mathrm{DDE}$ & ND & $2.00 \pm 0.00$ & $21.00 \pm 10.00$ \\
\hline$o, p-D D T$ & $0.143 \pm 0.030$ & $17.00 \pm 10.00$ & $3.00 \pm 0.00$ \\
\hline $\mathrm{p}, \mathrm{p}^{\prime}-\mathrm{DDT}$ & $0.020 \pm 0.00$ & ND & $1.00 \pm 0.00$ \\
\hline$\sum$ DDT & 0.266 & 22.00 & 41.00 \\
\hline Endrinaldehyde & $0.010 \pm 0.000$ & $1.00 \pm 0.00$ & ND \\
\hline Endrinketone & $0.020 \pm 0.000$ & $1.00 \pm 0.00$ & ND \\
\hline$\sum \mathrm{OCP}$ & $1.152 \pm 0.270$ & $73.00 \pm 30.00$ & $128.00 \pm 30.00$ \\
\hline
\end{tabular}

ND -Not detected: Values represent mean \pm SD $(n=3)$ 
For the dry season samples, $0.512 \mu \mathrm{g} / \mathrm{L}$ was the highest concentration obtained for Aldrin in the water samples and $0.01 \mu \mathrm{g} / \mathrm{L}$ was recorded for endrinaldehyde and $\delta-\mathrm{HCH} . \alpha-\mathrm{HCH}, \beta-\mathrm{HCH}, \varepsilon-$ $\mathrm{HCH}, \mathrm{HCB}, \mathrm{o}, \mathrm{p}-\mathrm{DDE}$ were not detected in the water samples. For the sediment samples $18.00 \mathrm{ng} / \mathrm{g}$ was the highest pesticide concentration recorded for endrin while the lowest concentration of $1.00 \mathrm{ng} / \mathrm{g}$ was obtained for $\delta$ - HCH, o, p - DDD, p, p' - DDD, and p, p' - DDE while $\beta-\mathrm{HCH}, \varepsilon-$ $\mathrm{HCH}$, heptachlor, $\gamma$ - heptachlor and p, p' - DDT were not detected.

$\sum \mathrm{HCH}$ and $\sum \mathrm{DDT}$ were determined of the sediment, water and fish samples for both sampling seasons. For the water samples $\sum \mathrm{HCH}$ concentrations was found to be lower than the concentration reported in the Yellow River $(1.10 \mu \mathrm{g} / \mathrm{L})$, Ebro River $(3.38 \mu \mathrm{g} / \mathrm{L})$, Illushi River $(4.89 \mu \mathrm{g} / \mathrm{L})$ (Table 3). Total DDT concentrations in the sediment samples from the study area ranged from not detected to $5.00 \mathrm{ng} / \mathrm{g} \mathrm{dw}$, with an average of $1.83 \mathrm{ng} / \mathrm{g} \mathrm{dw}$.

Comparison of the rainy and dry season means values revealed the fish samples as the most contaminated samples compared to the sediment and water samples. The results for the sediment showed that the dry season sample was more contaminated with OCPs than its rainy season counterpart. The value for the water sample followed the sediments pattern as the dry season sample was highly concentrated than the rainy season (Fig. 1). The total OCPs in the study site contributed by the matrix is shown in Fig. 2.

Table 3: OCPs residues in surface waters $(\mathrm{ng} / \mathrm{L})$ and sediments $(\mathrm{ng} / \mathrm{g} \mathrm{dw})$ reported in different locations

\begin{tabular}{lllll}
\hline Region & Date & $\sum$ HCH & $\sum$ DDTs & Reference \\
\hline Surface water & & & & \\
\hline Nigeria (Illushi River) & 2016 & 4.89 & 0.99 & {$[17]$} \\
Spain (Ebro River) & $1995-1996$ & 3.38 & 3.40 & {$[18]$} \\
Turkey (Kucuk Menderes River) & $2002-2003$ & $187-337$ & $72-120$ & {$[19]$} \\
China (Yellow River) & 2013 & 1.10 & 1.46 & {$[20]$} \\
Sediment & & & & \\
China (Pearl River Estuary) & 1998 & $0.28-1.23$ & $1.36-8.99$ & {$[21]$} \\
Taiwan (Wu-Shi River Estuary) & 1998 & $0.99-14.5$ & $0.53-11.4$ & {$[10]$} \\
China (Yellow River) & 2013 & 0.56 & ND & {$[20]$} \\
\hline
\end{tabular}

$\mathrm{ND}=$ not detected

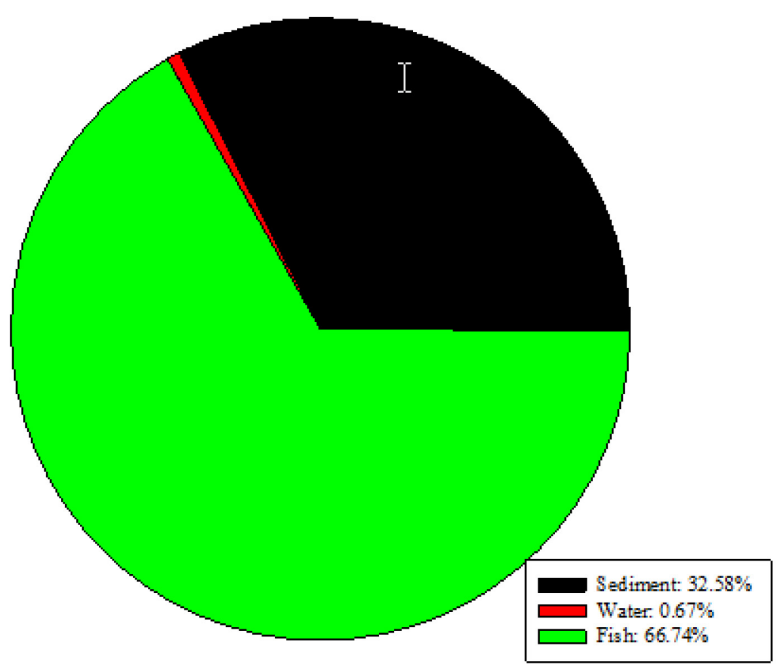

Figure 2: Total percentage distribution of OCPs in the three matrices for both seasons

Technical DDT is typically composed of $77.1 \% p, p^{\prime}$-DDT, $14.9 \% o, p^{\prime}$-DDT, $4 \% p, p^{\prime}$-DDE and some other trace impurities [22]. In this study, $o, p^{\prime}$-DDT was found to be the predominant metabolite obtained in the sediment, fish and water samples during the rainy season (Table 2). 
However, for the dry season, $p$, $p$ '-DDT was the predominant metabolite for the sediment samples only while the same trend was obtained as above for the water and fish samples. Generally, the $o, p^{\prime}$-DDT/ $p, p^{\prime}$-DDT ratio ranged from 0.2 to 0.3 in technical DDTs and from 1.3 to 9.3 or higher in dicofol [23]. Therefore, sources of DDTs (from technical DDT or dicofol impurities or both) can be identified according to the ratio of $o, p^{\prime}$-DDT/ $p, p^{\prime}$-DDT [24]. In this study, the ratios of $o, p^{\prime}$-DDT/ $p, p^{\prime}$-DDT in water, fish and sediment samples were 8.50, 0.01, and 4.00, respectively for the rainy season and 7.15,3.00 for the water and fish samples respectively for the dry season, indicating dicofol as the major source of DDT concentration reported.

DDT degrades to DDE and DDD in aerobic and anaerobic conditions, respectively [10]. In general, a ratio of (DDE + DDD)/DDTs of more than 0.5 indicates long-term biotransformation of DDT to DDE and DDD, while a ratio of less than 0.5 may indicate recent input of DDT [20,25]. The ratios of (DDE + DDD)/DDTs found in the Ethiope River was found to be 0.63, 0.29, 9.25 for water, sediment, and fish samples, respectively for rainy season and $0.53,1.2$ and 0.8 for water, sediment and fish samples respectively for the dry season. The finding that all values except sediment samples were higher than 0.5 indicating that the DDT compounds in Ethiope River may be mainly derived from DDT-treated aged and weathered agricultural sources as similarly reported by other authors [20]. Moreover, a higher ratio of $p, p$-DDE $/ p, p$-DDT can be used to indicate the long range atmospheric transport of DDT compounds because $p, p$-DDE is transported more efficiently than $p, p$-DDT $[20,26]$. This ratio can also be used to establish if the DDT emission occurred recently or in history [27-29]. The ratios of $p, p$-DDE/ $p, p$-DDT varied from 1.5 to 16 (Table 4) in the multiple environments of the river studied, indicating that the DDTs in this area may also come from atmospheric deposition [30]. Thus, the concentration of DDT obtained from the Ethiope river is as a result of the dicofol use from agricultural activities and also from atmospheric deposition. Also, a p, p’ - DDE/DDT $>1$ indicates old inputs of DDT and values $<1$ indicates fresh input [31]. The relatively high detection rates of DDT indicate that a small amount of DDT input may still occur in this area despite the ban. $\gamma-\mathrm{HCH}$ was found to be the predominant isomer in the water, fish and sediment samples in both the dry season and rainy season (Tables 1 and 2).

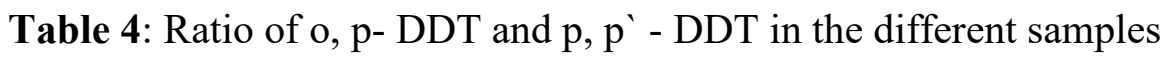

\begin{tabular}{lllllll}
\hline & \multicolumn{3}{c}{ Rainy Season } & \multicolumn{3}{c}{ Dry Season } \\
\hline & Water & Sediment & Fish & Water & Sediment & Fish \\
$\mathbf{0 ,}, \mathbf{p}-$ DDT & 0.170 & 2.00 & 4.00 & 0.143 & 17.00 & 3.00 \\
$\mathbf{p}, \mathbf{p}$ - DDT & 0.02 & 3.00 & 1.00 & 0.020 & - & 1.00 \\
\hline Ratio & 8.5 & 0.67 & 4.00 & 7.15 & - & 3.00 \\
\hline
\end{tabular}




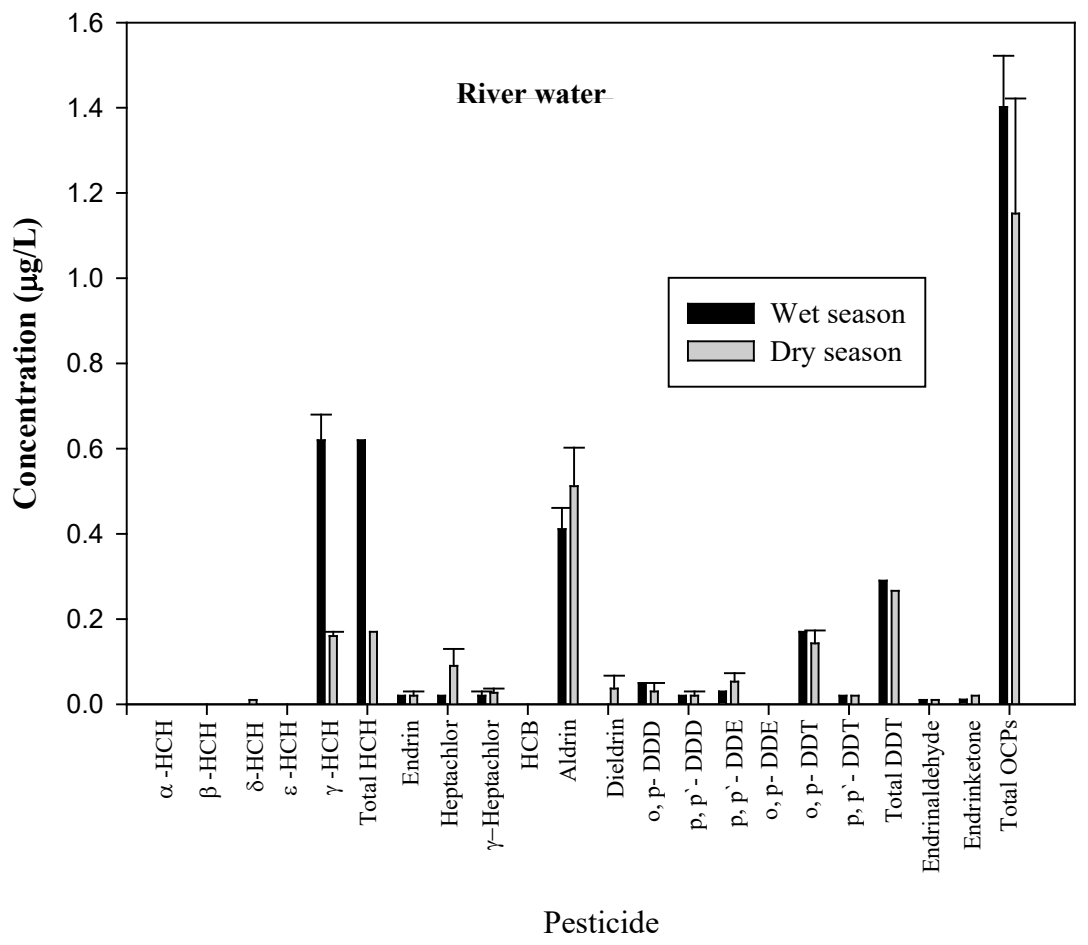

Figure 3: Seasonal variations of the OCPs studied in the River water samples

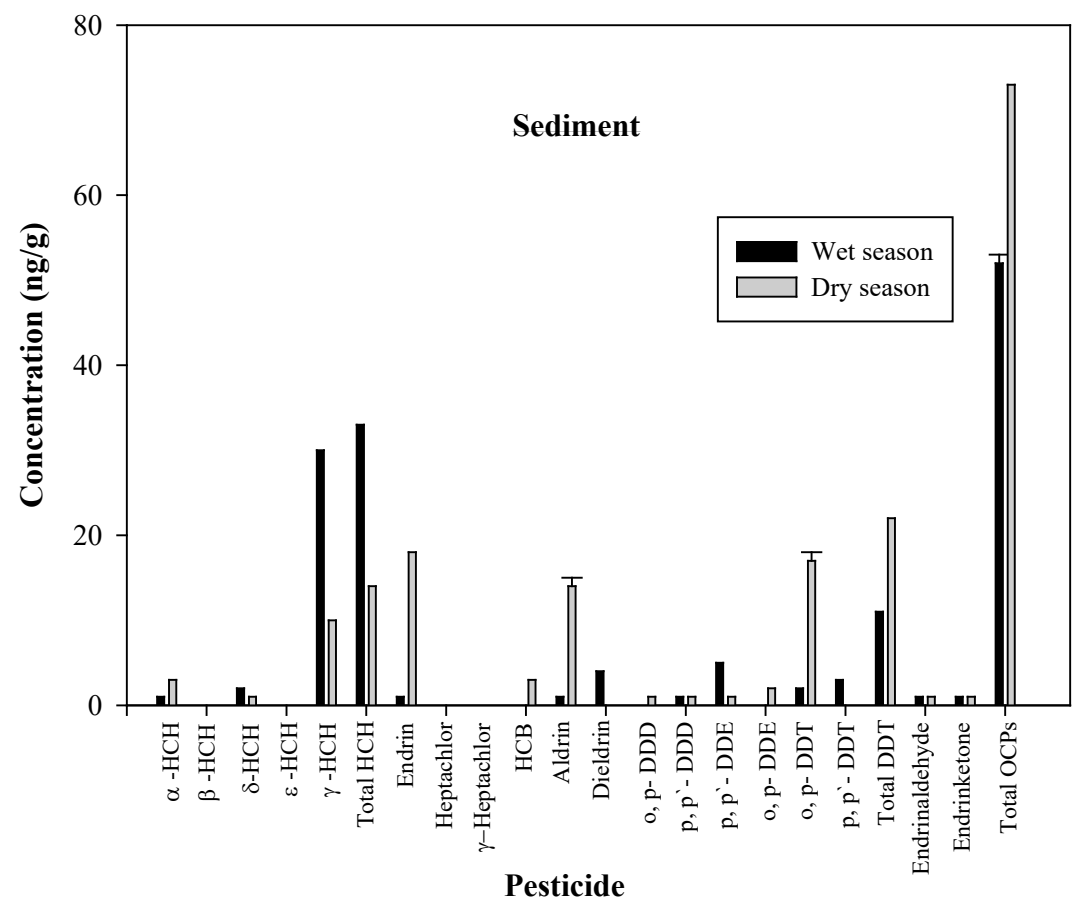

Figure 4: Seasonal variations of OCPs studied in sediment samples 


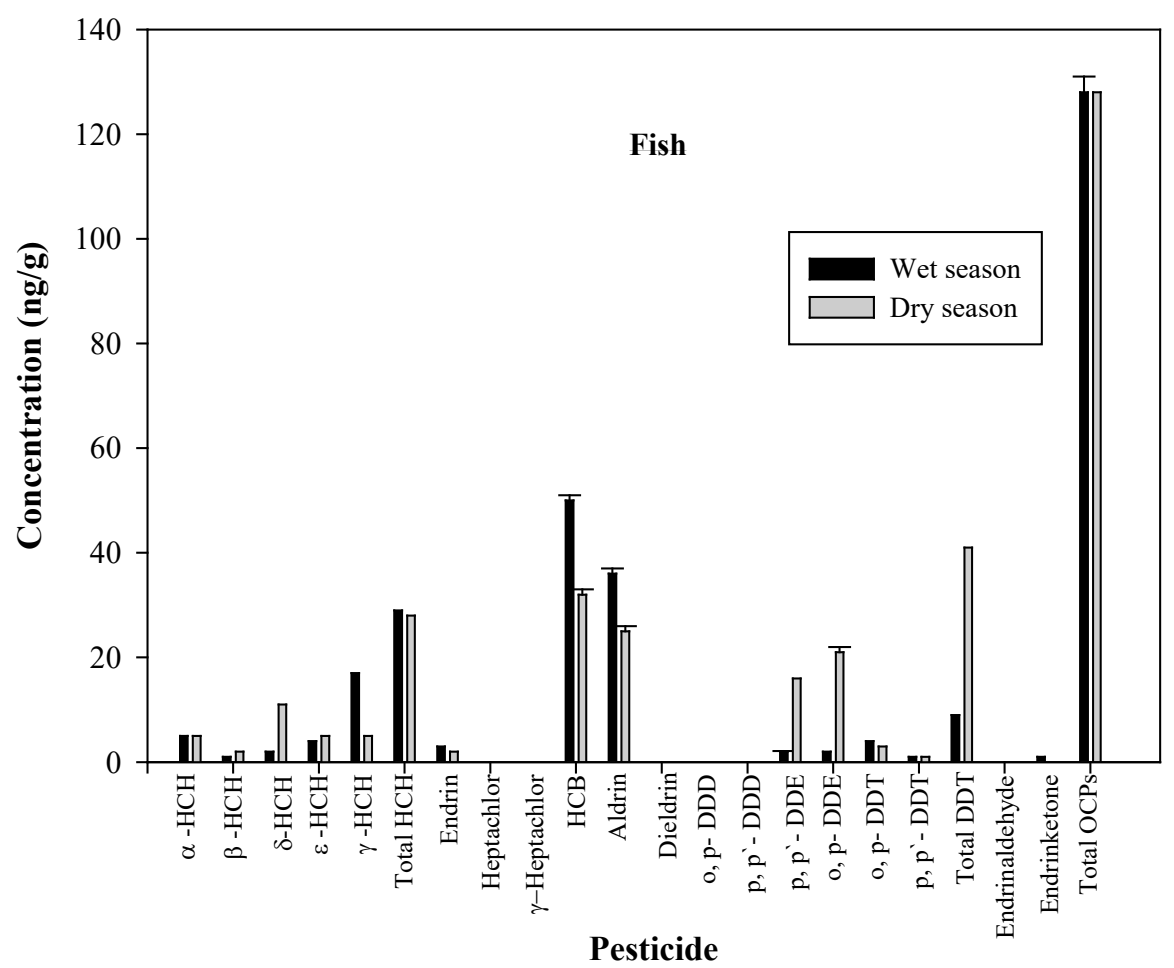

Figure 5: Seasonal variation of OCPs in fish samples studied

Table 5 indicates a statistical inference on the difference between measured OCPs with a specified reference level $(0.1 \mathrm{mg} / \mathrm{kg})$. The result for t-test shows that the measured OCPs is not significantly different from the acceptable reference level (i.e. $t$-calculated $<\mathrm{t}$-statistics $(n-1,0.95)$. This analysis is based upon calculated mean values, where $n$ is the total number of components that composes the measured OCPs.

Table 5: Student's t-test for fish sample

\begin{tabular}{lccc}
\hline Season & $\begin{array}{c}\left(\sum \mathbf{O C P s}\right) / \mathbf{n} \\
\text { concentration } \\
\mathbf{~ m g / k g}\end{array}$ & t-calculated & t-statistics (n-1, 0.95) \\
\hline Rainy & 0.004 & 0.5825 & \\
Toxicity & 0.005 & & \\
Reference level & 0.006 & 0.6614 & \\
Dry & 0.005 & & \\
Toxicity & Reference level & & \\
\hline
\end{tabular}

The hazard quotient (HQ) analysis carried out on the fish sample for both the rainy and dry season (Table 6) revealed that the fishes possesses the possibility of ecological concern to the inhabitants of the sample location (Table 3). The HQ approach compares environmental concentrations of a contaminant with the measured effect or no - effect level in test organisms [32]. Guidelines for interpreting HQ calculations are: $\mathrm{HQ}=<0.1$ (no hazard exists); $\mathrm{HQ}=0.1-1.0$ (hazard is low); HQ $=1.1-10$ (hazard is moderate); HQ $=>10$, (hazard is high). Values of HQ obtained for the both the rainy and dry season where found to be in the range $0.1-10$ indicating a low hazard [33]. 
Table 6: Hazard quotient for fish sample

\begin{tabular}{lcc}
\hline Season & $\begin{array}{c}\sum \text { OCPs concentration } \\
\mathbf{m g} / \mathbf{k g}\end{array}$ & HQ \\
\hline Rainy & 0.078 & 0.780 \\
Toxicity & 0.100 & \\
Reference level & & 1.280 \\
Dry & 0.128 & \\
Toxicity & 0.100 & \\
Reference level &
\end{tabular}

The bioaccumulation index (BI) of the fish samples in the sample site which showed that the fishes where not suitable for consumption as all the values were $>1$, and this possess a great possibility for ecological concern (Table 7).

Table 7: Bioaccumulation Index for fish samples

\begin{tabular}{llll}
\hline & & \multicolumn{2}{c}{$\sum$ OCPs concentration } \\
\hline Season & Fish & Water & BI \\
\hline Rainy season & 78.000 & 1.402 & 91.298 \\
Dry season & 128.000 & 1.152 & 111.111 \\
\hline
\end{tabular}

\section{Conclusion}

The study revealed clear presence of 21 OCPs at varying concentrations across the three matrices: water, sediment, fish (T. Zilli) in Ethiope River. The bioaccumulation index (BI) and hazard quotient (HQ) values for all studied site were all $>1$. This calls for a serious monitoring strategy to check the purchase, distribution, use and disposal of the OCPs as it affects the ecosystem and the environment as degradation of some of these OCPs takes a long time which gives room for bioaccumulation. Constant monitoring of OCPs level in Ethiope River will go a long way towards preventing various ecological, environmental and public health hazard as most of the populace in this studied locations depend on the rivers for their livelihood.

\section{Conflict of Interest}

The authors of this paper listed above certify that they have NO affiliations with or involvement in any organization or entity with any financial interest (such as honoraria; educational grants; participation in speakers' bureaus; membership, employment, consultancies, stock ownership, or other equity interest; and expert testimony or patent-licensing arrangements), or non-financial interest (such as personal or professional relationships, affiliations, knowledge or beliefs) in the subject matter or materials discussed in this manuscript. 


\section{References}

[1] J. Feng, M. Zhai, Q. Liu, J. Sun, J. Guo, Residues of organochlorine pesticides (OCPs) in upper reach of the Huaihe River, East China. Ecotoxicology and Environmental Safety. 74 (2011) 2252-2259.

[2] S.Y. Wei, M.I. Leong, Y. Li, S.D. Huang, Development of liquid phase microextraction based on manual shaking and ultrasound- assisted emulsification method for analysis of organochlorine pesticides in aqueous samples. Journal of Chromatography A. 1218 (2011) 9142-9148.

[3] X. Zhao, Y. Zhou, W. Kong, B. Gong, D. Chen, J. Wei, M. Yang, Multi-residue analysis of 26 organochlorine pesticides in Alpinia oxyphylla by GC-ECD after solid phase extraction and acid cleanup. Journal of Chromatography B. 1017-1018 (2016) 211-220.

[4] D.A. Lambropoulou, T.A. Albanis, Liquid phase micro-extraction techniques in pesticides residue analysis. Journal of Biochemical and Biophysical Methods. 70 (2006) 3.

[5] H. Kuranchie-Mensah, S.M. Atiemo, L.M.N.D. Palm, S. Blankson-Arthur, A.O. Tutu, P. Fosu, Determination of organochlorine pesticide residue in sediment and water from the Densu river basin, Ghana. Chemosphere. 86, (2012) 286-292.

[6] L. Yuan, S. Qi, X. Wu, C. Wu, X. Xing, X. Gong, Spatial and temporal variations of organochlorine pesticides (OCPs) in water and sediments from Honghu Lake, China. Journal of Geochemical Exploration. 132 (2013) 181-187.

[7] F. Kafilzadeh, Assessment of Organochlorine Pesticide Residues in Water, Sediments and Fish from Lake Tashk, Iran. Achievements in the Life Sciences. 9 (2015) 107-111.

[8] R.O. Meire, M. Khairy, A.C. Targino, P.M.A. Galvão, J.P.M. Torres, O. Malm, R. Lohmann, Use of passive samplers to detect organochlorine pesticides in air and water at wetland mountain region sites (S-SE Brazil). Chemosphere. 144 (2016) 2175-2182.

[9] L. Singh, S. Choudhary, P.K. Singh, Pesticide concentration in water and sediment of River Ganga at selected sites in Ganga plain. International Journal of Environmental Sciences. 3 (2012) 260-274.

[10] R.A. Doong, Y.C. Siun, P.L. Liao, C.K. Peng, S.C. Wu, Distribution and fate of organochlorine pesticides residues in sediments from selected rivers in Taiwan. Chemosphere. 48 (2002) 237-246.

[11] S.K. Golfinopoulos, A.D. Nikolaous, M.N. Kostopoulou, N.K. Xilourgidis, M.C. Vagi, D.T. Lekkas, Organochlorine pesticides in the surface waters of Northern Greece. Chemosphere. 50 (2003) 507-516.

[12] H. Bouman, South Africa and the Stockholm on Persistent organic pollutants. African Journal of Science. 100 (2004) 323-328.

[13] C. Blaso, G. Font, Y. Pico, Analysis of pesticides in fruits by pressurized liquid extraction and liquid chromatography-ion trap -triple stage mass spectrometry. Journal of Chromatography A. 1098 (2005) 37-43.

[14] D. Adeyemi, C. Anyakora, G. Ukpo, A. Adedayo, G. Darko, Evaluation of the levels of organochlorine pesticide residues in water samples of Lagos lagoon using solid phase extraction method. Journal of Environmental Chemistry and Ecotoxicology. 3 (2011).

[15] L.F. Awosika, Impacts of global climate change and sea level rise on coastal resources and energy development in Nigeria. Global Climate Change: Impact on Energy Development. Nigeria, (1995).

[16] H. Maier-Bode, Properties, effect, residues and analytics of the insecticide endosulfan. Residue Review. 22 (1968) 1-44. 
[17] O. Ogbeide, I. Tongo, L. Ezemonye, Assessing the distribution and human health risks of organochlorine pesticide residues in sediments from selected rivers. Chemosphere. 144 (2016) 1319-1326.

[18] M.A. Fernandez, C. Alonso, M.J. Gonzalez, L.M. Hernandez, Occurrence of organochlorine insecticides, PCB and PCB congeners in waters and sediments of the Ebro River (Spain). Chemosphere. 38 (1999) 33-43.

[19] C. Turgut, The contamination with organochlorine pesticides and heavy metals in surface water in Kucuk Menderes River in Turkey, 2000-2002. Environment International. 29 (2003) 29-32.

[20] J. Li, F. Li, Q. Liu, Sources, concentrations and risk factors of organochlorine pesticides in soil, water and sediment in the Yellow River estuary. Marine Pollution Bulletin. 100 (2015) 516-522.

[21] H.S. Hong, W.Q. Chen, L. Xu, X.H. Wang, L.P. Zhang, Distribution and fate of organochlorine pollutants in the Pearl River estuary. Marine Pollution Bulletin. 39 (1999) 376-382.

[22] K. Kannan, S. Tanabe, R. Tatsukawa, Geographical distribution and accumulation features of organochlorine residues in fish in tropical Asia and Oceania. Environmental Science and Technology. 29 (1995) 2673-2683.

[23] X.H. Qiu, T. Zhu, B. Yao, J.X. Hu, S.W. Hu, Contributions of dicofol to the current DDT pollution in China. Environmental Science and Technology. 39 (2005) 4385-4390.

[24] X. Yang, S. Wang, Y. Bian, F. Chen, G. Yu, C. Gu, X. Jiang, Dicofol application resulted in high DDTs residues in cotton fields from northern Jiangsu province, China. Journal of Hazardous Materials. 150 (2008) 92-98.

[25] R.K. Hitch, H.R. Day, Unusual persistence of DDT in some western USA soils. Bulletin of Environmental Contamination and Toxicology. 48 (1992) 259-264.

[26] H. Iwata, S. Tanabe, N. Sakal, R. Tatsukawa, Distribution of persistent organochlorines in the oceanic air and surface seawater and the role of ocean on their global transport and fate. Environmental Science and Technology. 27 (1993) 1080 -1098.

[27] K. Pozo, T. Harner, M. Shoeib, R. Urrutia, R. Barra, O. Parra, S. Focardi, Passive - sampler derived air concentrations of persistent organic pollutants on a north-south transect in Chile. Environmental Science and Technology. 38 (2004) 6529-6537.

[28] X.H. Wang, N.Q. Ren, H. Qi, W.L. Ma, Y.F. Li, Levels, distributions and source identification of organochlorine pesticides in the topsoils in Northeastern China. Journal of Environmental Science. 21 (2009) 1386-1392.

[29] Q. Zhang, Z. Chen, Y. Li, P. Wang, C. Zhu, G. Gao, K. Xiao, H. Sun, S. Zheng, Y. Liang, G. Jiang, Occurrence of organochlorine pesticides in the environmental matrices from King George Island, west Antarctica. Environmental Pollution. 206 (2015) 142-149.

[30] G. Dai, X. Liu, G. Liang, X. Han, L. Shi, D. Cheng, W. Gong, Distribution of organochlorine pesticides (OCPs) and poly chlorinated biphenyls (PCBs) in surface water and sediments from Baiyangdian Lake in North China. Journal of Environmental Science. 23 (2011) 1640-1649.

[31] A. Cabrerizo, J. Dachs, D. Barcelo, K.C. Jones, Influence of organic matter content and human activities on the occurrences of organic pollutants in Antartic soils, lichens, grass and mosses. Environmental Science and Technology. 49 (2012) 1396-1405.

[32] A.D. Lemly, Evolution of the hazard quotient method for risk assessment of selenium. Ecotoxicology and Environmental Safety. 35 (1996) 156-162.

[33] H. Feng, H.Y. Jiang, W.S. Gao, M.P. Weinstein, Q.F. Zhang, W.G. Zhang, L.Z. Yu, D.K. Yuan, J.H. Tao, Metal contamination in sediments of the western Bohai Bay and adjacent estuaries, China. Journal of Environmental Management. 92 (2011) 1185-1197. 